Article

\title{
Tourism Demand Elasticities by Income and Prices of International Market Regions: Evidence Using Vietnam's Data
}

\author{
Quang Hai Nguyen ${ }^{1,2}$ (D)
}

1 Faculty of Business Administration, University of Economics and Law, Ho Chi Minh City 71309, Vietnam; nhquang@uel.edu.vn

2 Vietnam National University, Ho Chi Minh City 71309, Vietnam

\begin{abstract}
This study aims to determine tourism demand elasticities by income and prices of regions, as well as total international markets. It is deployed to a total of 10 major source markets and two separate regions, from Asia and intercontinental to Vietnam. The results of data analysis for the period 1995-2019 and using a nonlinear panel ARDL approach show that tourism demand from major Asian markets to Vietnam is strongly income elastic, but tourism demand from major intercontinental markets to Vietnam is relatively price inelastic. Tourism demand in intercontinental markets is less elastic to price, but in Asian markets it is quite price sensitive, especially own price elasticities. In addition, different effects of income and prices are found in most of the major markets. Study results have provided useful insights into different types of tourism goods and price sensitivity between market regions, as well as the degree of substitute destinations.
\end{abstract}

Keywords: tourism demand elasticities; income and prices; international market regions

\section{Introduction}

Tourism is an important and potential service industry in many countries around the Tourism Demand Elasticities by Income and Prices of International Market Regions: Evidence Using Vietnam's Data. Economies 10: 1. https://doi.org/10.3390/ economies10010001

Academic Editor:

Aleksander Panasiuk

Received: 28 October 2021

Accepted: 15 December 2021

Published: 21 December 2021

Publisher's Note: MDPI stays neutral with regard to jurisdictional claims in published maps and institutional affiliations.

Copyright: (C) 2021 by the author. Licensee MDPI, Basel, Switzerland. This article is an open access article distributed under the terms and conditions of the Creative Commons Attribution (CC BY) license (https:// creativecommons.org/licenses/by/ $4.0 /)$. world. Therefore, researching which is related to tourism demand, has been a concern of many economists and researchers for decades. Crouch (1992) reviewed and pointed out that there are at least 44 studies related to tourism demand in the period 1960-1990. In addition, Song et al. (2010) added 17 studies from 2000 to 2009. After the study of Song et al. (2010), additional studies related to tourism demand were found (Chaiboonsri et al. 2010; Lee 2011; Kraipornsak 2011; Seetaram 2012; Cheng 2012; Gatta and Falzon 2014; Álvarez-Diaz et al. 2015; Lin et al. 2015; Untong et al. 2015; Seetaram et al. 2016; Dogru et al. 2017; Ramos et al. 2017; Dogru and Sirakaya-Turk 2018; Xu et al. 2018; Shafiullah et al. 2018; Kumar et al. 2020). These studies have enriched the theory and method of measuring the elasticity or forecasting the model of tourism demand in different contexts. Nevertheless, studies have not yet reached a consensus on the common factors that affect tourism demand and the most effective modelling and forecasting techniques (Peng et al. 2014).

Dogru et al. (2017, p. 47) pointed out that "early studies focused on measurement issues related to the proper identification of independent variables, the conceptualization of variables, and proxies acceptable for these variables, while recent studies tend to focus more on modelling and forecasting techniques and the data levels to be used". An interesting issue is that tourism prices are often not available and are composed of many complex factors. Therefore, there are many different views on defining representative prices for own price and substitute prices. Moreover, these different views lead to certain different results. Furthermore, initial studies only looked at tourism demand from one country to another. However, recently, researchers have tended to define origins and destinations that are more diverse, such as total international visitors to a country ( $\mathrm{Xu}$ et al. 2018); visitors from countries to a country and total international visitors to a country (Chaiboonsri et al. 2010; Kumar et al. 2020); total outbound visitors of a country (Seetaram 2012; Seetaram 
et al. 2016); and total international visitors to different regions of a country (Shafiullah et al. 2018). However, the author has not found studies that consider source markets as different regions (groups of countries). This issue is also worthy of interest since it provides useful insights into the differences of demand elasticities by income and prices in different market sectors, as a basis for proposing tourism business policies for each market region.

Vietnam is located in the ASEAN region, in the lower Mekong region, and is a country with rich and diversified tourism potentials. Therefore, tourism is considered a key economic sector. The travel and tourism sector directly contributed USD 24.3 billion to Vietnam's GDP in 2019, accounting for 9.2\% (Vietnam National Administration of Tourism 2020), of which international tourism plays a key role. The travel and tourism sector not only contributes directly to the GDP and jobs, but also brings a significant foreign currency and accelerates Vietnam's international integration process. Therefore, the study of tourism demand has become essential for Vietnam. However, the author has not found studies examining the elasticity of international tourism demand in Vietnam. These are the motivations to be carried out for this study.

The objective of this study is to determine the tourism demand elasticities by income and prices of the major international source and region markets to Vietnam. The research results will provide useful insights into the different types of tourism goods and price sensitivities across regions and the total international arrivals market, as well as the degree of substitute destinations in the Lower Mekong region for Vietnam.

In the next section, the paper presents the literature review, followed by a presentation of the methodology and data. Then, the paper presents the research results and discusses the implications given from the research results. Finally, the paper ends with a few tentative conclusions.

\section{Literature Review}

The tourism demand elasticity has been tested through a large number of studies at different times and contexts. These studies give evidence for the role of income and prices in the international tourism market demand in different countries. According to Samirkaş and Samirkaş (2015, p. 1177), "tourism demand is defined as the number of people that plan to buy tourism products supported by sufficient purchasing power and spare time in order to meet tourism needs of people". To measure tourism demand, researchers have used a number of different indicators. Crouch (1992) showed that visitor arrivals are commonly used as the dependent variable for tourism demand models in studies from the 1960s to the 1990s. Song et al. (2010) summarized and presented four main groups that are used as tourism demand proxies. However, the authors also argue that tourist arrivals, as measured by the total number of tourists arriving in a country from another country, is a suitable proxy for demand, as Crouch (1992) pointed out. Recently, this view has been accepted by a majority of scholars (Seetaram et al. 2016; Dogru et al. 2017; Ramos et al. 2017; Shafiullah et al. 2018; Dogru and Sirakaya-Turk 2018; Xu et al. 2018; Kumar et al. 2020).

There are many factors that affect tourism demand. First, it must be seen that tourists' income is an important factor that affects tourism demand. In general, when income increases, people have more money to travel and the role of income is confirmed in most of the studies related to tourism demand. According to Lim (1997), discretionary income is the best measure of income, but this data is often not available. Therefore, data related to people's income are often used by researchers as a proxy for tourist income, such as real GDP (Dogru et al. 2017; Ramos et al. 2017; Kumar et al. 2020); real GDP per capita (Kraipornsak 2011; Lee 2011; Dogru and Sirakaya-Turk 2018; Xu et al. 2018); GDP index (Song and Wong 2003; Lin et al. 2015; Untong et al. 2015); per capita income index (Li et al. 2006); and GDP per capita based on purchasing power parity (PPP) (Seetaram 2012). Consistent with the general theory, most of the studies in different areas and times have found that tourists are often sensitive to tourism demand. Generally, the arrivals are positively correlated with the tourists' income from the source country. In other words, as income increases, people tend to increase their overseas travel demand. In this case, the 
coefficient of income elasticity above unity (greater than 1) implies that tourism is a luxury good, and in the case of under unity (less than 1), it is an essential good. However, in some cases, a negative income elasticity is also found. In addition, Crouch (1996) suggested that this is a sign of "inferior" good or destinations.

Herein, it can be seen that the size of the population in the source country is a potential factor of tourists. Therefore, without considering the population of the source country as a factor that affects tourism demand, the per capita income provides a greater meaning than using the GDP. This not only represents the income of tourists, but also reflects the population size of the source country. According to the macroeconomic theory, the GDP per capita PPP is a tool to compare the economic productivity and standard of living of the people of a country. In addition, it is adjusted to the currency parity by the exchange rate for a basket of equally priced goods. Therefore, the GDP per capita PPP is not only related to the GDP per capita, but also related to the exchange rate and CPI. Therefore, it has a certain correlation with the exchange rate and CPI. This shows that using the GDP per capita PPP, exchange rate, and CPI as independent variables that affect the international tourism demand will probably lead to the phenomenon of multicollinearity, as mentioned by Martin and Witt (1989) and Dogru et al. (2017) in the case of using both the CPI and exchange rate. Therefore, if tourism demand is viewed in the context of CPI and exchange rate as an influencing factor, the real GDP per capita is considered as a suitable proxy variable.

Along with income, prices are also the critical factors that affect tourism demand, including own price (tourism price) and substitute destination price. Tourism services at the destination are related to many factors, such as transportation services, accommodation services, meals, sightseeing, entertainment, etc. Ideally, both the own and substitute prices should be measured using the Tourist Price Index, which is a combination of goods and services that tourists consume (Martin and Witt 1989). However, in reality, determining the price of travel services is very difficult and the tourist price index is not always available. Furthermore, according to Martin and Witt (1989), the difference between the tourist price index and CPI is not significant. Therefore, CPI is often used as the basis for constructing tourist price data in the absence of tourism price data (Álvarez-Diaz et al. 2015; Lin et al. 2015; Untong et al. 2015; Seetaram et al. 2016; Dogru et al. 2017; Shafiullah et al. 2018; Kumar et al. 2020).

For international tourism, prices are related not only to prices at destinations, but also to prices at departure, such as services at the departure airport, transportation costs or bilateral exchange rates for transferring to the destination currency. Therefore, in the case of using CPI as the basis for calculating the proxy value of prices, the bilateral exchange rate between the country of origin and the country of destination is also a factor related to the tourism prices. However, the determination of proxy data for international tourism prices (own and substitute price) based on the CPI and exchange rate is still a subject of discussion.

Initially, many researchers used the destination CPI as a proxy for prices (Song and Witt 2003; Song et al. 2003; Croes and Vanegas 2005; Álvarez-Diaz et al. 2015). However, Dogru et al. (2017, p. 49) pointed out that own price is known as the relative price and should be measured as "the price in a destination relative to the price in the tourist-originating country. In addition, it captures the effects of price differences between the origin country and receiving destinations." Therefore, using the ratio of the destination country's CPI to the source country's CPI as a proxy for prices will more fully reflect the cost of international travel.

Next, many studies have used the real exchange rate as an independent variable that affects tourism demand (Croes and Vanegas 2005; Chaiboonsri et al. 2010; Kraipornsak 2011; Shafiullah et al. 2018). However, it can be seen that the CPI and real exchange rate are two proxies of prices and always move together. Therefore, they are highly correlated, and when using these two variables at the same time, this can lead to multicollinearity (Martin and Witt 1989; Dogru et al. 2017). As a result, "prices standardized by the appropriate 
exchange rate, for both relative and substitute prices, need to be used as a proxy for the cost of tourism" (Dogru et al. 2017, p. 50). This view has been supported by many studies on tourism demand (Seetaram 2012; Cheng 2012; Gatta and Falzon 2014; Seetaram et al. 2016; Ramos et al. 2017; Xu et al. 2018; Kumar et al. 2020).

As a general rule, empirical studies have shown that most of the own price elasticity of demand has a negative sign. An elasticity of less than -1 implies that tourism demand is price sensitive, and from -1 to 0 , this implies that tourism demand is less price elastic. However, in some cases, the positive own price elasticity is also found, such as from India, Malaysia, and Singapore to Thailand (Kraipornsak 2011) or from some countries from Europe to Turkey (Dogru et al. 2017). According to Crouch (1996, p. 122), the sign of price elasticity can be positive if there is an "occurrence of a high income effect and/or a complementary relationship with alternative destinations". In addition, Dogru et al. (2017, p. 52) showed that "a positive price elasticity of demand might be an indication of Giffen (or inferior) or Veblen (or luxury) goods depending on the income effect on the demand". For the substitute price, it usually has a positive sign. However, it is sometimes found to be a negative sign in certain markets and this is an indication that it is a complementary destination.

Although rarely used, in addition to income and prices (including the CPI and exchange rate), some studies also use other independent variables, such as economy airfare (Kulendran and Witt 2001); transportation costs (Dritsakis 2004; Chaiboonsri et al. 2010; Kraipornsak 2011); transportation price index (Shafiullah et al. 2018); the accommodation capacity (Ouerfelli 2008); population size (Xu et al. 2018), etc. However, it can be seen that the population size is a component of GDP per capita, economy airfare, transportation cost, average oil price, and the accommodation capacity, which are also good components related to the CPI and exchange rate. Therefore, if the GDP per capita is used as a proxy for income, and the CPI and exchange rate are the basis for calculating a proxy for prices, most of the above factors are related to the GDP per capita, CPI, and exchange rate.

In addition to the quantitative factors, "there are a large number of qualitative and other factors that influence the decision to consume international tourism, including special events, political instability and social conflict, airlift problems, travel restrictions, economic recession, etc." (Vanegas and Croes 2000, p. 951). Therefore, dummy variables are often used to explain the effect of special events that may temporarily impact tourism demand. "A dummy variable takes the value of one for some observations to indicate the presence of an effect or membership in a group and zero for the remaining observations" (Greene 2008, p. 106).

In the last few decades, scholars have proposed a variety of techniques for estimating parameters in tourism demand models. Initially, linear regression was applied (e.g., Uysal and Crompton 1984). Then, the log-log model became popular since the natural logarithmic also reduces the instability of the data (Enders 2004; Studenmund 2006) and the log-log model allows for the attainment of the coefficients directly (Song et al. 2009). In the early years of the 21st century, the ordinary least squares (OLS) or base on OLS were widely used to estimate the time series or panel data (Vanegas and Croes 2000; Kulendran and Witt 2001; Lim 2004; Croes and Vanegas 2005; Munoz 2007). However, the OLS regression may lead to a spurious regression if the variables are not stationary (Granger and Newbold 1974).

To avoid spurious regression problems in nonstationary data, several advanced estimation techniques have been used. Among them, cointegration regression with two popular tools, fully modified ordinary least squares (FMOLS) and dynamic ordinary least squares (DOLS), are said to be powerful tools since they describe "the existence of an equilibrium or stationary relationship among two or more time-series, each of which is individually non-stationary" (Banerjee et al. 1994, p. 136). Furthermore, Dogru et al. (2017, p. 49) pointed out that "the FMOLS estimator corrects the serial correlation and endogeneity problems that are encountered in the OLS technique. Another advantage of FMOLS estimation is that it offers both a pooled and grouped mean estimator". Therefore, it is also an appropriate method if the data are suitable (for example, in the study of Seetaram et al. 2016; Dogru 
et al. 2017; Dogru and Sirakaya-Turk 2018). However, the cointegration regression needs an assumption that the variables in the model are all non-stationary at $\mathrm{I}(0)$, but stationary at I(1) and cointegrated of order 1. Moreover, "methods of cointegration are not reliable for small sample sizes" (Narayan and Narayan 2005, p. 429).

To overcome the above limitations, Pesaran et al. (2001) proposed an autoregressive distributed lag (ARDL) model. This estimator is superior to other basic regression estimators since it allows its application "irrespective of whether the underlying variables are I(0) or I(1) or a combination of both" (Nkoro and Uko 2016, p. 78). Moreover, Song et al. (2003, p. 365) stated that "one of the advantages of the general ARDL is that a modern econometric technique, known as error correction, can be readily incorporated into the modelling process". On the other hand, according to the design, the ARDL estimator also gives the estimation coefficients in the long-run and short-run, as well as the short-run cross-sectional coefficients for each subject in the case of panel data. With many advantages, the ARDL estimator has been widely used in the tourism demand related model (Lee 2011; Lin et al. 2015; Álvarez-Diaz et al. 2015; Shafiullah et al. 2018; Kumar et al. 2020).

\section{Methodology and Data}

\subsection{Tourism Demand Model}

The literature review found that tourist income, own price, and substitute price are general and key factors that affect international tourism demand. In addition, qualitative factors that restrict travel, such as epidemics, political instability, economic recession, financial crisis, etc. are also considered as a factor that affects tourism demand. Therefore, to estimate the tourism demand elasticities by income and prices, this study applies the tourism demand function, which is suggested by Song et al. (2010) and shown in Equation (1) as follows:

$$
\mathrm{DT}_{\mathrm{i}, \mathrm{t}}=\mathrm{f}\left(\mathrm{IT}_{\mathrm{i}, \mathrm{t}}, \mathrm{TP}_{\mathrm{i}, \mathrm{t}}, \mathrm{SP}_{\mathrm{i}, \mathrm{t}}, \mathrm{X}_{\mathrm{i}, \mathrm{t}}\right)+\mathrm{U}_{\mathrm{i}, \mathrm{t}}
$$

where $\mathrm{DT}_{i, t}$ is the tourism demand to Vietnam from the origin country i at year $t ; \mathrm{IT}_{i, t}$ is the income level of tourists in the origin country $i$ at year $t$; $\mathrm{TP}_{i, t}$ is the tourism price to Vietnam from the origin country $i$ at year $t ; \mathrm{SP}_{\mathrm{i}, \mathrm{t}}$ is the substitute price for the tourist from the origin country $i$ at year $t$ (tourism price in competitive destinations); and $X_{i, t}$ is the dummy variable that represents the qualitative factors from the origin country $i$ at time $t$.

As discussed in the literature review, the log-log model (nonlinear) has many advantages, thus they are applied in this study. In addition, this study uses the visitor arrivals and per capita income of the source country as a proxy for tourism demand and tourist income. Since the tourism price from the source markets to Vietnam and to the substitute destinations are not available, the own and substitute prices are calculated based on the $\mathrm{CPI}$ and exchange rate. To be more specific, the own price is the relative price, measured as the ratio of Vietnam's CPI to the CPI in the source country and adjusted for the bilateral exchange rate. Equation (2) describes the own price as the relative price standardized by the bilateral exchange rate (Seetaram et al. 2016; Dogru et al. 2017; Ramos et al. 2017; Xu et al. 2018; Kumar et al. 2020), as follows:

$$
\mathrm{TP}_{\mathrm{i}, \mathrm{t}}=\frac{\mathrm{CPI}_{\mathrm{v}, \mathrm{t}}}{\mathrm{CPI}_{\mathrm{i}, \mathrm{t}} * \mathrm{ER}_{\frac{\mathrm{v}}{\mathrm{v}}, \mathrm{t}}}
$$

where $\mathrm{CPI}_{v, t}$ is the CPI in Vietnam at year $t ; \mathrm{CPI}_{i, t}$ is the CPI of the origin country $i$ at year $t$; and $E R_{\frac{i}{V}, t}$ is the bilateral exchange rate of country i's currency to Vietnam Dong at year $t$.

Similar to the own price, the substitute price is also standardized by the bilateral exchange rate and is measured by the weighted average of the substitute destinations (Dogru et al. 2017; Ramos et al. 2017; Kumar et al. 2020), as shown in Equation (3) as follows:

$$
S P_{i, t}=\sum_{s=1}^{n} W_{s, t} \frac{C P I_{s, t}}{C P I_{i, t} * E_{\frac{i}{s}, t}}
$$


where $\mathrm{CPI}_{s, t}$ is the CPI in the substitute country s's at year $t ; \mathrm{ER}_{\frac{i}{\mathrm{~s}}, \mathrm{t}}$ is the bilateral exchange rate of country i's currency to country s's currency; and $W_{s, t}$ is the weight for substitute $s$ at year $t$ and is measured as the tourist market share (Mangion et al. 2005; Song and Li 2008; Ramos et al. 2017; Kumar et al. 2020). This is shown in Equation (4) as follows:

$$
\mathrm{W}_{\mathrm{s}, \mathrm{t}}=\sum_{\mathrm{s}=1}^{\mathrm{m}} \frac{\mathrm{TA}_{\mathrm{is}, \mathrm{t}}}{\mathrm{TA}_{\mathrm{i}, \mathrm{t}}}
$$

where $\mathrm{TA}_{\mathrm{is}, \mathrm{t}}$ is the total number of the arrivals from country $\mathrm{i}$ to country $\mathrm{s}$ in year $\mathrm{t}$; and $\mathrm{TA}_{i, t}$ is the total number of outbound tourists to substitute destinations from country $i$ in year $t$.

In this study, the substitute destinations for Vietnam were identified as the remaining countries in the lower Mekong River, namely Cambodia, Laos, Malaysia, Myanmar, and Thailand. The countries in this region are located close to each other, share the same Mekong River, and have relatively similar economies and cultures, thus they can be considered as substitutes for each other.

\subsection{Sample and Data}

This study uses data from the 10 largest international tourist markets to Vietnam, namely China, Korea Republic, Japan, the US, Malaysia, Australia, the UK, Singapore, France, and Germany in the period 1995-2019 (pre-Covid-19 period) to obtain a panel dataset with 250 observations for the overall sample. In 2019, the number of visitors from these 10 countries to Vietnam was 5.81, 4.29, 0.95, 0.75, 0.61, 0.38, and 0.32 million, respectively. The selection of these 10 source markets is due the fact that these 10 markets accounted for more than $70 \%$ of visitors to Vietnam in the period 1995-2019. Therefore, they can represent the number of international visitors to Vietnam. On the other hand, the rest of the markets are not big enough or have not enough data for the whole period 1995-2019. Data on international arrivals to Vietnam are collected from the General Statistics Office (GSO) of Vietnam and VNAT. Descriptive statistics on arrivals from these 10 countries for the period 1995-2019 are shown in Table 1.

Table 1. International tourist and descriptive statistics in the period 1995-2019.

\begin{tabular}{|c|c|c|c|c|c|c|c|c|}
\hline \multirow[b]{2}{*}{ Country } & \multicolumn{3}{|c|}{ To Vietnam (1995-2019) } & \multicolumn{5}{|c|}{ Descriptive Statistics } \\
\hline & Tourists & CARG & Proportion & Mean & Maximum & Minimum & $\begin{array}{l}\text { Standard } \\
\text { Deviation }\end{array}$ & $\begin{array}{l}\text { Coefficient } \\
\text { of Variation }\end{array}$ \\
\hline China & $35,081,325$ & $20.77 \%$ & $25.53 \%$ & $1,403,253$ & $5,806,425$ & 62,640 & $1,485,151$ & 1.06 \\
\hline Korea Rep. & $19,039,123$ & $21.99 \%$ & $13.85 \%$ & 761,565 & $4,290,802$ & 36,375 & $1,094,738$ & 1.44 \\
\hline Japan & $10,317,026$ & $9.03 \%$ & $7.51 \%$ & 412,681 & 951,962 & 95,258 & 254,619 & 0.62 \\
\hline The US & $9,285,132$ & $5.89 \%$ & $6.76 \%$ & 371,405 & 746,171 & 146,488 & 166,373 & 0.45 \\
\hline Malaysia & $4,757,314$ & $17.19 \%$ & $3.46 \%$ & 190,293 & 606,206 & 13,462 & 181,977 & 0.96 \\
\hline Australia & $4,959,124$ & $9.81 \%$ & $3.61 \%$ & 198,365 & 386,934 & 40,600 & 122,006 & 0.62 \\
\hline The UK & $3,258,704$ & $7.73 \%$ & $2.37 \%$ & 130,348 & 315,084 & 39,631 & 87,347 & 0.67 \\
\hline Singapore & $3,250,617$ & $11.15 \%$ & $2.37 \%$ & 130,025 & 308,969 & 24,437 & 96,333 & 0.74 \\
\hline France & $4,017,356$ & $3.78 \%$ & $2.92 \%$ & 160,694 & 287,655 & 67,000 & 70,503 & 0.44 \\
\hline Germany & $2,334,845$ & $10.60 \%$ & $1.70 \%$ & 93,394 & 226,792 & 20,206 & 63,295 & 0.68 \\
\hline Others & $41,124,065$ & $7.80 \%$ & $29.92 \%$ & 550,468 & $4,085,014$ & $1,644,963$ & $1,022,204$ & 0.62 \\
\hline Total & $137,424,630$ & $11.39 \%$ & $100.00 \%$ & $18,008,591$ & $1,351,300$ & $5,496,985$ & $4,500,652$ & 0.82 \\
\hline Asia sample & $72,445,404$ & $17.36 \%$ & $52.72 \%$ & $2,897,816$ & $11,964,364$ & $72,445,404$ & $3,049,227$ & 1.05 \\
\hline Other sample & $23,855,161$ & $6.62 \%$ & $17.36 \%$ & 954,206 & $1,959,213$ & $23,855,161$ & 502,061 & 0.53 \\
\hline
\end{tabular}

Source: Calculated from the data of General Statistics Office of Vietnam (2021) and Vietnam National Administration of Tourism (2021)

Data on the GDP per capita of source markets, CPIs of source markets, Vietnam and substitute destinations (Cambodia, Laos, Malaysia, Myanmar, and Thailand), as well as exchange rates of countries to the US dollar are collected from the data published by the World Bank. The base year is 1995 with a CPI of 100 to calculate the price of the following years. Based on these data, data on the bilateral exchange rate, own price, and substitute 
price are generated by Equations (2)-(4). The 10 largest international tourist markets to Vietnam can be divided into two groups: (1) Asian markets (China, Korea, Japan, Malaysia, and Singapore); (2) intercontinental markets, including three European countries (the UK, France, and Germany), one American country (the US), and one Australian country (Australia). The overall sample is divided into two sub-samples by these market regions to ensure that the dataset is large enough $(\mathrm{N}=5, \mathrm{~T}=25)$ and allows for the finding of different elasticity coefficients of these regions in the long-run. Descriptive statistics of the natural logarithm of the variables in the model of the three samples are shown in Table 2.

Table 2. Descriptive statistics of independent variables.

\begin{tabular}{ccccccc}
\hline Scheme & Variable & Mean & Maximum & Minimum & $\begin{array}{c}\text { Standard } \\
\text { Deviation }\end{array}$ & Observations \\
& $\operatorname{lnDT}$ & 12.1310 & 15.5745 & 9.5076 & 1.1677 & 250 \\
\multirow{3}{*}{ Overall } & $\operatorname{lnIT}$ & 10.026 & 11.1295 & 6.4129 & 0.9919 & 250 \\
& $\operatorname{lnTP}$ & 8.7047 & 11.3285 & 2.2408 & 2.4454 & 250 \\
& $\operatorname{lnSP}$ & 6.1314 & 9.5676 & -2.5640 & 2.8244 & 250 \\
\hline \multirow{3}{*}{ Asia } & $\operatorname{lnDT}$ & 12.4029 & 15.574 & 9.5076 & 1.3821 & 125 \\
& $\operatorname{lnIT}$ & 9.5231 & 11.1003 & 6.4129 & 1.1709 & 125 \\
& $\operatorname{lnTP}$ & 7.1249 & 10.7986 & 2.2407 & 2.5539 & 125 \\
Intercontinental & $\operatorname{lnSP}$ & 4.1908 & 7.72912 & -2.5257 & 2.5994 & 125 \\
& $\operatorname{lnDT}$ & 11.8590 & 13.5227 & 9.9137 & 0.8239 & 125 \\
& $\ln \mathrm{lT}$ & 10.5294 & 11.1294 & 9.8777 & 0.3068 & 125 \\
& $\operatorname{lnSP}$ & 10.2844 & 11.3285 & 8.9756 & 0.6736 & 125 \\
\hline
\end{tabular}

Source: Calculated from the data of The World Bank (2021), General Statistics Office of Vietnam (2021), and Vietnam National Administration of Tourism (2021).

In the period 1995-2019, there were three periods of negative growth in international tourist arrivals to Vietnam (1998: $-11.4 \%$; 2003: $-7.6 \%$; and 2009: $-11.5 \%$ ) due to the influence of the financial crisis in 1998, the SARS pandemic in 2003, and the economic recession of 2008-2009 (Figure 1). In addition, the largest international market to Vietnam and China has been hindered in two periods. First, relations between China and Vietnam only normalized in 1996. Therefore, in 1995, tourists from China to Vietnam encountered difficulties in visa regulations. Second, in 2015, China placed an oil rig in Vietnam's waters and the tension between the two countries affected tourists from China to Vietnam. Therefore, these instability events are dummy variables in the models. The dummy variable takes the value 1 in 1998, 2003, and 2009 for all of the markets, 1995 and 2015 for the China source market only (see Nguyen 2021), and the remaining years receive the value 0 .

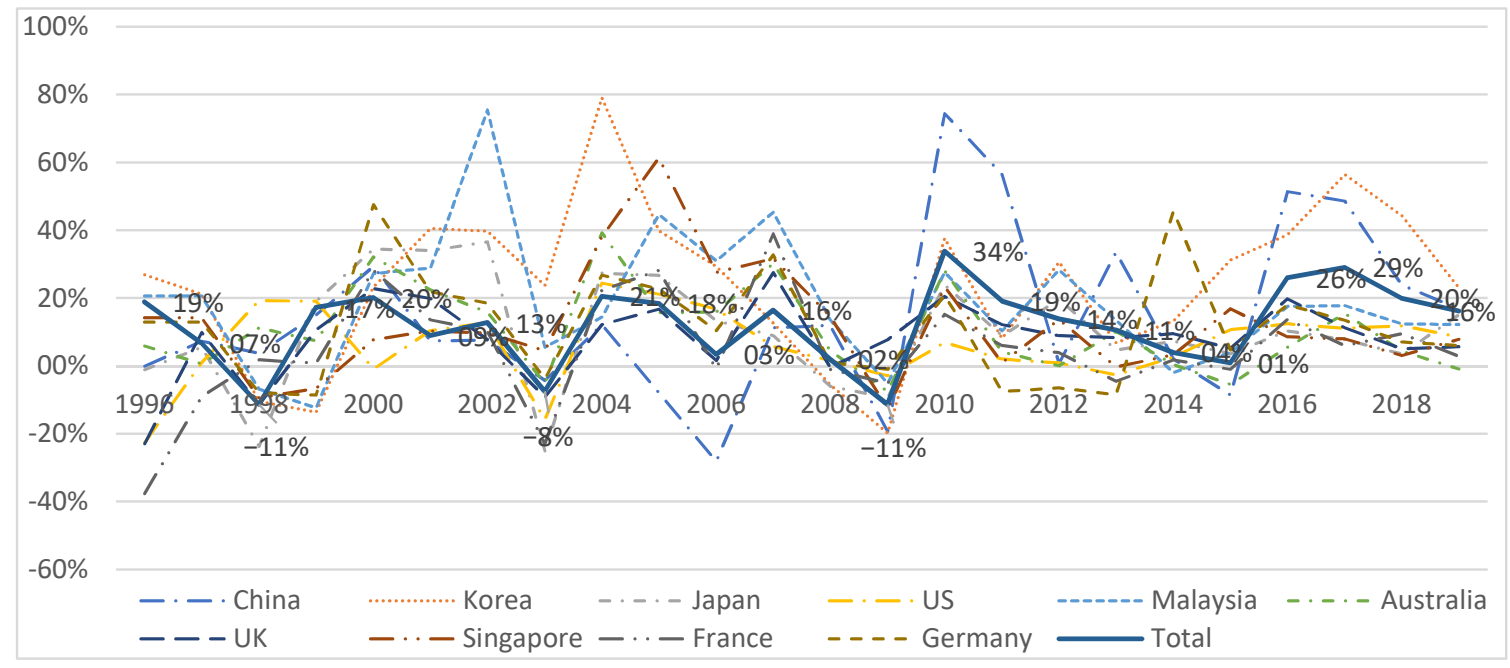

Figure 1. Growth of key international markets to Vietnam. 
According to Ritchie (2004) and Araña and León (2008), tourism demand is very sensitive to the uncertainty stemming from crises, such as political instability, natural disasters, and disease outbreaks. Furthermore, Salisu and Isah (2017) argued that the dynamic heterogenous panel data model is usually considered when non-stationarity is a concern. Therefore, the unit root test is used to check for the stationarity. With the balanced panel data, both of the assumptions, the common unit root process, and the individual unit root process, can be applied. Accordingly, the test of Levin, Lin, and Chu (LLC) is selected for the assumption of the common unit root process, and the test selected for the assumption of the individual unit root process is composed of Im, Pesaran, and Shin (IPS), Augmented Dickey Fuller (ADF), as well as Philips Peron (PS). Both patterns, "individual intercept" and "individual trend and intercept", are selected in the test and the lag length is automatically chosen by the Schwarz information criterion (SIC) with the Newey-West automatic bandwidth selection and the Bartlett kernel. The panel unit root test results are shown in Table 3.

Table 3. Results of panel unit root tests.

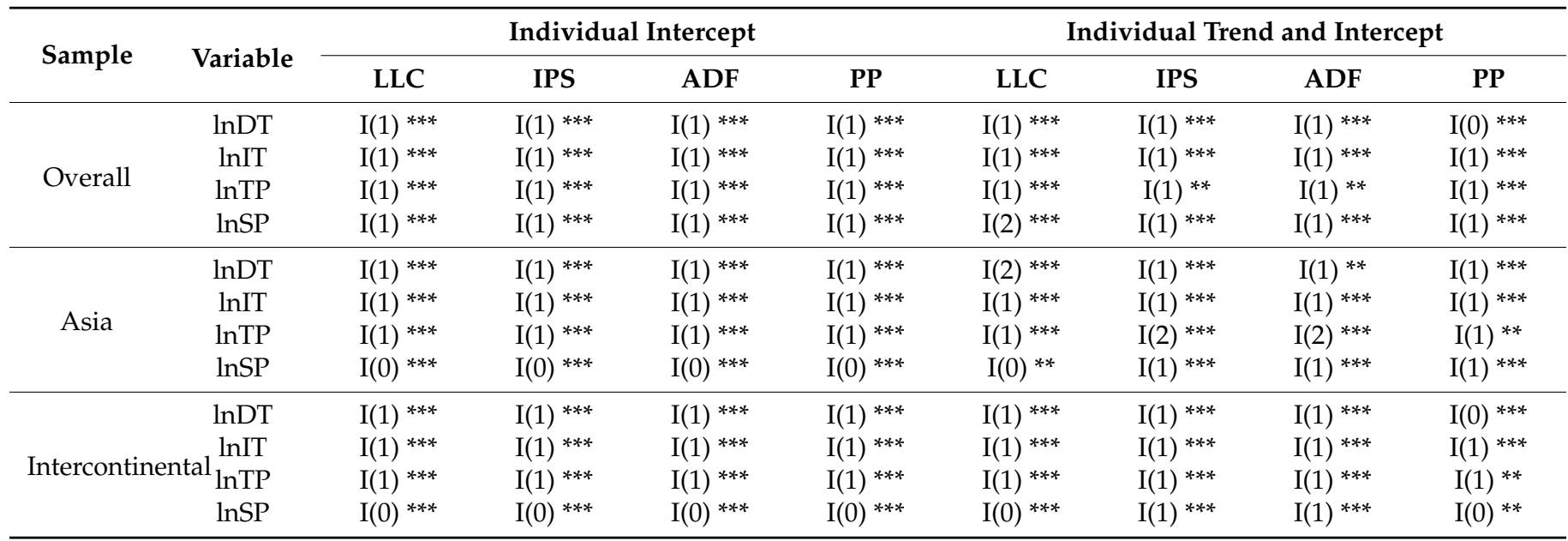

Note: LLC: Levin, Lin, and Chu; IPS: Im, Pesaran, and Shin W-stat; ADF: ADF-Fisher Chi-square; PP: PP—Fisher Chi-square; ${ }^{* *}$ and ${ }^{* * *}$ denote statistical significance at the 0.05 and 0.01 levels, respectively.

Table 3 shows that most of the tests are not significant at the 0.05 level for all variables in both the test in "individual intercept" as well as the "individual trend and intercept". Therefore, the null hypothesis of the unit test is not rejected, indicating that the variables are not stationary at level $\mathrm{I}(0)$ for most of the variables. However, when converting these series at first difference, most of the tests are significant at the 0.01 or 0.05 level for the variables. The results show that the variables contain a mixture of both I(1) and I(0), thus the ARDL estimator is appropriate for the data in this study (Nkoro and Uko 2016). Furthermore, the ARDL estimator has many advantages as discussed in the aforementioned literature review, especially for panel data. In addition to providing long-run and short-run estimated coefficients, it also provides short-term cross-sectional coefficients for each subject.

\subsection{Specification Estimation Model}

Based on the suggestion of Pesaran et al. (2001) and Kumar et al. (2020), the specification model estimated by the ARDL method for the panel data in this study is expressed in the form of Equation (5) as follows:

$$
\begin{aligned}
& \Delta \operatorname{lnDT}_{i, t}=\alpha_{i}+\sum_{j=1}^{q 1} \beta_{1 i} \Delta \operatorname{lnDT} T_{i, t-j}+\sum_{j=0}^{q 2} \beta_{2 i} \Delta \operatorname{lnIT} T_{i, t-j}+\sum_{j=0}^{q 3} \beta_{3 i} \operatorname{lnTP} P_{i, t-j}+\sum_{j=0}^{q 4} \beta_{4 i} \operatorname{lnSP}_{i, t-j}+\gamma_{o, i}+\gamma_{1, i} \operatorname{lnDT} T_{i, t-1} \\
& +\gamma_{2, \mathrm{i}} \ln \mathrm{IT}_{\mathrm{i}, \mathrm{t}-1}+\gamma_{3, \mathrm{i}} \ln \mathrm{PT} \mathrm{T}_{\mathrm{i}, \mathrm{t}-1}+\gamma_{4, \mathrm{i}} \ln \mathrm{PS} \mathrm{S}_{\mathrm{i}, \mathrm{t}-1}+\mathrm{X}_{\mathrm{i}, \mathrm{t}}+\varepsilon_{\mathrm{i}, \mathrm{t}} \\
& \mathrm{i}=1,2, \ldots \mathrm{N} ; \mathrm{t}=1,2, \ldots \mathrm{T}
\end{aligned}
$$


where $\alpha_{i}$ is the group-specific effect; $i$ is the source country; $t$ is the number of year; $-1<$ $\gamma_{1}<0$ is the error correction term's coefficient; $\varepsilon_{i, t}$ is the error term; $\Delta$ is the first difference operator; $\mathrm{j}$ is the lag order decided by the Akaike information criterion (AIC); and ln is the natural logarithm. For each cross-section, the long-run elasticity of income, own price, and substitute price is calculated as $-\frac{\gamma_{2 \mathrm{i}}}{\gamma_{1 \mathrm{i}}},-\frac{\gamma_{3 \mathrm{i}}}{\gamma_{1 \mathrm{i}}},-\frac{\gamma_{4 \mathrm{i}}}{\gamma_{1 \mathrm{i}}}$, respectively. Therefore, the short-run estimates of income, own price, and substitute price are $\beta_{2 \mathrm{i}}, \beta_{3 \mathrm{i}}, \beta_{4 \mathrm{i}}$, respectively.

\section{Results and Discussion}

\subsection{Results}

\subsubsection{Coefficient Estimation}

By design, the ARDL method for panel data has two estimators, known as the mean group (MG) and pooled mean group (PMG). According to Blackburne and Frank (2007, p. 199), the PMG estimator "allows the intercept, short-run coefficients, and error variances to differ across the groups (as would the MG estimator), but constrains the long-run coefficients to be equal across groups (as would the FE estimator)". Therefore, the PMG/ARDL estimator is chosen to estimate the elasticity coefficients. The lag is automatically selected with a maximum of 2, the Akaike information criterion (AIC) is chosen in the model selection, and the "linear trend" is chosen in the trend specification. Table 4 summarizes the regression results using the PMG/ARDL estimator for all of the three samples in the long-run and short-run.

According to Table 4, the automatic lag chosen for both the regressor and the independent variables is 2 in all of the three samples. In the statistics, the log-likelihood is quite large and the remaining statistics in the three samples are relatively small. Therefore, the models are appropriate and fit with the data. In the long-run equation, the variables of interest are $\operatorname{lnIT}, \operatorname{lnTP}$, and $\operatorname{lnSP}$ in all of the three samples, which are significant at the 0.01 level, thus they are accepted. The signs of the coefficients are as expected and according to the general rule. To be more specific, the income $(\operatorname{lnIT})$ and the substitute price $(\operatorname{lnSP})$ have a positive sign, while the own price $(\ln \mathrm{TP})$ has a negative sign. The dummy variable $(\mathrm{X})$ is only significant in the overall sample with a negative sign, as expected.

Table 4. Results of panel estimation by the PMG estimator.

\begin{tabular}{|c|c|c|c|c|c|c|}
\hline \multirow{2}{*}{ Variable } & \multicolumn{2}{|c|}{ Overall Sample } & \multicolumn{2}{|c|}{ Asia Sample } & \multicolumn{2}{|c|}{ Intercontinental Sample } \\
\hline & Coefficient & t-Statistic & Coefficient & t-Statistic & Coefficient & t-Statistic \\
\hline \multicolumn{7}{|l|}{ Long-Run Equation } \\
\hline LOG(IT) & 1.0268 & $7.3412 * * *$ & 2.7718 & $16.3323^{* * *}$ & 0.8371 & $4.8364 * * *$ \\
\hline LOG(TP) & -0.5450 & $-5.4776^{* * *}$ & -1.2429 & $-8.4753^{* * *}$ & -0.3612 & $-2.3036 * *$ \\
\hline LOG(SP) & 0.1821 & $8.9896^{* * *}$ & 0.5497 & $9.5667^{* * *}$ & 0.1524 & $8.0919^{* * *}$ \\
\hline$x$ & -0.2055 & $-2.2963^{* *}$ & 0.0603 & 0.6750 & -0.0412 & -0.4619 \\
\hline \multicolumn{7}{|l|}{ Short-Run Equation } \\
\hline COINTEQ01 & -0.3922 & $-3.6110^{* * *}$ & -0.3195 & -1.6151 & -0.4327 & $-2.4678^{* *}$ \\
\hline$\Delta \mathrm{LnDT}$ & 0.0825 & 1.1124 & 0.2126 & $2.3679 * *$ & -0.0283 & -0.3127 \\
\hline$\Delta \mathrm{LnIT}$ & 0.0684 & 0.4178 & -0.0580 & -0.1117 & -0.1357 & -0.6188 \\
\hline$\Delta \operatorname{LnIT}_{(-1)}$ & 0.1525 & 0.3329 & -0.3557 & -0.4125 & 0.6567 & 1.5757 \\
\hline$\Delta \mathrm{LnTP}$ & 0.2164 & 1.2571 & 0.1207 & 0.2633 & 0.3854 & $4.4173^{* * *}$ \\
\hline$\Delta \operatorname{LnTP}_{(-1)}$ & -0.3472 & $-1.7519 *$ & -0.2474 & -0.8718 & -0.5752 & $-2.2208^{* *}$ \\
\hline$\Delta \operatorname{LnSP}$ & -0.0303 & -0.7201 & -0.0554 & -1.2138 & -0.0505 & -0.7983 \\
\hline$\Delta \operatorname{LnSP}_{(-1)}$ & -0.1102 & $-2.4437^{* *}$ & -0.1981 & $-2.0899 * *$ & -0.0652 & $-2.2911^{* *}$ \\
\hline$\Delta X^{\prime}$ & -0.0441 & $-1.8996 *$ & -0.1447 & $-5.4968^{* * *}$ & -0.0862 & $-3.7898^{* * *}$ \\
\hline$\Delta \mathrm{X}_{(-1)}$ & -0.0594 & $-3.2575^{* * *}$ & -0.1181 & $-3.8767^{* * *}$ & -0.0735 & $-2.8919 * * *$ \\
\hline$C^{-11}$ & 1.7251 & $4.3774 * * *$ & -2.6211 & -1.3425 & 2.1158 & $2.5222 * *$ \\
\hline @Trend & 0.0343 & $3.1823 * * *$ & 0.0064 & 0.8600 & 0.0273 & $2.5880 * *$ \\
\hline \multicolumn{7}{|l|}{ Statistics } \\
\hline S.E. of regression & & 0.0983 & & 0.1229 & & 0.0747 \\
\hline Sum squared residual & & 1.2168 & & 0.9216 & & 0.3406 \\
\hline Log-likelihood & & 304.1710 & & 128.8731 & & 177.2918 \\
\hline Akaike info criterion & & -1.4414 & & -1.0380 & & -1.8127 \\
\hline
\end{tabular}


For the short-run equation, the cointegration equations are negative in the overall and intercontinental sample with significance at the 0.01 level, indicating that a long-run relationship exists between the independent and dependent variables. These two cases imply that the variables converge to the long-run equilibrium and the convergence rate is $39.22 \%$ and $43.27 \%$, respectively. Most of the coefficients for $\ln \mathrm{DT}$, $\ln \mathrm{IT}$, and $\operatorname{lnTP}$ are not significant at the 0.05 level for all of the three samples, except for $\operatorname{lnDT}$ in the Asian sample with positive coefficients, as well as $\operatorname{lnSP}$ in the intercontinental sample with different coefficients depending on the lag. The coefficients of $\operatorname{lnSP}$ and the dummy variable $(X)$ both found significance in all of the three samples with a negative sign (lnSP at 2-year lag; dummy variable $(X)$ at both the 1- and 2-year lag in the Asian and intercontinental sample, at 2-year lag in the overall sample). The coefficient of the intercept and trend is significant at the 0.01 level with a positive sign for both the overall and intercontinental sample, but it shows no significance in the Asian sample. Therefore, in the short-run, autoregression is found only in the Asian market. In addition, the own price has an impact on tourism demand in the intercontinental market, and the substitute price and uncertain factors have an impact on tourism demand in the Asian, intercontinental, and overall market.

To determine the tourism demand elasticities by income and prices, as well as the effects of uncertain factors in each source market, short coefficients are extracted from the results of the PMG/ARDL analysis. Table 5 shows the short-run coefficients for each cross-section.

According to Table 5, the cointegration equations all have negative coefficients and are significant at the 0.01 level, showing that a long-run relationship exists between the independent and dependent variables. In addition, the convergence to the long-run equilibrium is observed in all of the 10 largest source markets of Vietnam. In this case, the convergence rate is highest in Australia (87.88\%) and lowest in the UK (8.85\%). All of the trend coefficients are positive and significant at the 0.01 level, indicating that the international tourism demand to Vietnam from all of these source markets has an increasing trend, increasing from 0.0077 to 0.1207 . In descending order, the markets are Japan, Australia, Malaysia, France, Korea, Germany, Singapore, China, the US, and the UK, respectively. The intercept is significant for only four markets with decreasing positive coefficients: Malaysia, Germany, Korea, and the UK, respectively. The intercept coefficient is significant for only four markets with a decreasing positive coefficient, namely Malaysia, Germany, Korea, and the UK, respectively. Dummy variables $(X)$ are significant at the 0.01 level in all of the source markets at both the 1- and 2-year lag. Negative coefficients are found in most of the source markets, except for Japan and Australia, indicating that uncertainties have negatively affected most of the source markets.

The coefficients of lnDT are significant in most of the source markets, except for Korea and Australia. In this case, five markets with decreasing positive coefficients are Malaysia, Singapore, Japan, China, and the US, respectively, while three markets with increasing negative coefficients are Germany, the UK, and France, respectively. The different signs and magnitudes of the coefficients show different autoregressive trends of short-run tourism demand in these source markets. For lnIT, only 5/10 coefficients are significant, but with a different sign mostly at the 2-year lag, except for Malaysia at the 1-year lag. In this case, positive signs are found in the source markets of Germany, Singapore, and Malaysia, while the negative sign is found in the source markets of China and Australia. Next, most of the lnTP variables are significant in source markets with different signs and lags. Specifically, except for Japan and Singapore, $\operatorname{lnTP}$ is significant in the remaining eight source markets. In this case, the elasticity is negative in Germany, Korea, and the UK at the 2-year lag; the elasticity is positive in China and Australia at the 1-year lag; and the elasticity coefficients change the sign in Malaysia, the US, and France between the 1- and 2-year lag. In general, at the 2-year lag, lnTP has a positive sign in these markets, except for Malaysia. Finally, despite the different signs, most of the markets are found to have at least one lag where the $\operatorname{lnSP}$ variable is significant, except for China. However, most of the lnSP coefficients are negative (Malaysia, Japan, Germany, Korea, and Australia) and some are both negative and 
positive signs depending on the lag (the US, France, and the UK). Here, the only coefficient in Singapore is a positive sign. These results suggest different roles of income and prices in different source markets in the short-run.

Table 5. Cross-section of short-run coefficients.

\begin{tabular}{|c|c|c|c|c|c|c|c|c|c|c|}
\hline & China & Korea & Japan & The US & Malaysia & Australia & The UK & Singapore & France & Germany \\
\hline COINTEQ01 & $-\underset{* * *}{0.1893}$ & $-\underset{* * *}{0.1647}$ & -1.1140 & $-\underset{* * *}{0.1207}$ & $-\underset{* * *}{0.4043}$ & $-\underset{* * *}{-0.8788}$ & $-\underset{* * *}{0.0885}$ & $-\underset{* * *}{0.1827}$ & $-\underset{* * *}{0.4085}$ & -0.3701 \\
\hline$\Delta \mathrm{LnDT}$ & $\underset{* * *}{0.1380}$ & $\underset{*}{0.1247}$ & $\underset{* * *}{0.2127}$ & $\underset{* * *}{0.1070}$ & $\underset{* * *}{0.4979}$ & 0.0005 & $\underset{* *}{-0.0791}$ & $\underset{* * *}{0.2618}$ & $\underset{* *}{-0.0560}$ & $-\underset{* * *}{0.3823}$ \\
\hline$\Delta \mathrm{LnIT}$ & 0.3103 & 0.6033 & -0.1833 & 0.7951 & $\underset{* *}{0.4950}$ & $-\underset{*}{0.2350}$ & -0.1427 & 0.3614 & $\begin{array}{c}-0.7257 \\
*\end{array}$ & -0.5944 \\
\hline$\Delta \operatorname{LnIT}_{(-1)}$ & -3.3247 & 1.4358 & -0.5805 & $\underset{*}{1.6215}$ & 0.1095 & $\underset{* *}{-0.2412}$ & 0.0046 & $\underset{* *}{0.7070}$ & 0.2351 & $\underset{* * *}{1.5585}$ \\
\hline$\Delta \mathrm{LnTP}$ & $\underset{* *}{1.2171}$ & -0.3514 & 0.0104 & $\underset{* * *}{0.6059}$ & $-\underset{* * *}{0.7203}$ & $\underset{* * *}{0.4921}$ & $\underset{*}{0.1235}$ & -0.0841 & $\underset{* *}{0.4433}$ & $\begin{array}{c}0.4273 \\
*\end{array}$ \\
\hline$\Delta \operatorname{LnTP}_{(-1)}$ & -0.0482 & $-\underset{* *}{1.0790}$ & 0.0944 & $-\underset{* * *}{0.5753}$ & $\underset{* * *}{0.7308}$ & -0.0214 & $-\underset{* * *}{0.2742}$ & -0.2749 & $\underset{* *}{-0.5121}$ & -1.5122 \\
\hline$\Delta \mathrm{LnSP}$ & -0.0072 & -0.0386 & $\underset{* * *}{-0.2506}$ & $\underset{* * *}{0.1299}$ & $\underset{* *}{-0.0503}$ & $\underset{* * *}{-0.1469}$ & $\underset{* * *}{-0.0202}$ & $\underset{* *}{0.1800}$ & $\underset{* * *}{0.0638}$ & $\underset{* * *}{-0.1616}$ \\
\hline$\Delta \operatorname{LnSP}_{(-1)}$ & $\underset{*}{-0.0184}$ & $-\underset{* * *}{0.1556}$ & $\underset{* * *}{-0.2100}$ & $-\underset{* * *}{0.1161}$ & $\underset{* * *}{-0.4608}$ & $\underset{* * *}{-0.0723}$ & $\underset{* * *}{0.0320}$ & -0.0253 & $\underset{* * *}{-0.0388}$ & $\underset{* * *}{-0.0363}$ \\
\hline$\Delta \mathrm{X}$ & $-\underset{* * *}{0.0705}$ & $-\underset{* * *}{0.0907}$ & $\underset{* * *}{0.0881}$ & $-\underset{* * *}{0.1028}$ & $-\underset{* * *}{0.0921}$ & $\underset{* * *}{0.0900}$ & $-\underset{* * *}{0.1080}$ & $\underset{* * *}{-0.0520}$ & $-\underset{* * *}{-0.0597}$ & $\underset{* * *}{-0.0432}$ \\
\hline$\Delta \mathrm{X}_{(-1)}$ & $-\underset{* * *}{-0.0338}$ & $\underset{* * *}{-0.0530}$ & $\underset{* * *}{0.0221}$ & $\underset{* * *}{-0.0171}$ & $\underset{* * *}{-0.1483}$ & $\underset{* * *}{0.0245}$ & $\underset{* * *}{-0.0913}$ & $\underset{* * *}{-0.0954}$ & $\underset{* * *}{-0.0932}$ & $\underset{* * *}{-0.1081}$ \\
\hline $\mathrm{C}$ & 1.9394 & $\underset{* *}{0.4955}$ & 3.5716 & 0.5720 & $\begin{array}{c}2.1382 \\
* *\end{array}$ & 3.9257 & $\underset{* * *}{0.4384}$ & $\begin{array}{c}0.7311 \\
*\end{array}$ & $\begin{array}{c}1.8304 \\
*\end{array}$ & $\underset{* *}{1.6092}$ \\
\hline @Trend & $\underset{* * *}{0.0091}$ & $\underset{* * *}{0.0282}$ & $\underset{* * *}{0.1207}$ & $\underset{* * *}{0.0077}$ & $\underset{* * *}{0.0426}$ & $\underset{* * *}{0.0543}$ & $\underset{* * *}{0.0087}$ & $\underset{* * *}{0.0146}$ & $\underset{* * *}{0.0299}$ & $\underset{* * *}{0.0269}$ \\
\hline
\end{tabular}

Note: LnDT is the dependent variable; ${ }^{* * *},{ }^{* *}$ and ${ }^{*}$ denote significance at the $0.01,0.05$, and 0.10 levels, respectively.

\subsubsection{Diagnostic Test and Robustness Check}

Diagnostic tests are performed to further consider the reliability and validity of the estimated coefficients. Two types of diagnostic tests in EVIEW are proposed for the panel PMG/ARDL method, namely coefficient diagnosis and residual diagnosis. According to the asymptotic theory, when the observation size is large enough, the test of the normal distribution of the residuals can be omitted (Wooldridge 2015). In this study, the number of observations is 250 for the overall sample and 125 for the subsamples, allowing for the residual diagnosis to be ignored. The coefficient diagnostic test is performed through the coefficient confidence interval and the Wald test is performed with the Null Hypothesis, in which the coefficients are all equal to 0 . Table 6 presents the results of coefficient diagnosis.

As shown in Table 6, with 95\% and 99\% confidence intervals, the values of the coefficients of $\operatorname{lnIT}, \operatorname{lnTP}, \operatorname{lnSP}$, and $X$ of all three samples are on one side. In more detail, the maximum and minimum values of $\operatorname{lnIT}$ and $\operatorname{lnSP}$ are both greater than 0 . By contrast, the maximum and minimum values of $\operatorname{lnTP}$ and $X$ are both less than 0 . The F- and Chi-squared statistics are both significant at the 0.01 level in all three samples, allowing the null hypothesis to be rejected. This indicates that the estimated coefficients in the models are all non-zero and the variables are all necessary in the models of the three samples.

The robustness check is performed by comparing the PMG/ARDL estimate with other suitable regression methods. As shown above, most of the tests show that the variables are stationary at the first difference. Therefore, the cointegration test is performed. The cointegration test results in all of the three samples in Appendix A show that the variables have a long-term relationship, thus it can be estimated by the cointegration regression. 
Table 6. Coefficient diagnostics.

\begin{tabular}{|c|c|c|c|c|c|c|c|c|}
\hline \multirow{3}{*}{ Sample } & \multirow{3}{*}{ Variable } & \multicolumn{5}{|c|}{ Coefficient Confidence Intervals } & \multirow{2}{*}{\multicolumn{2}{|c|}{$\begin{aligned} \text { Wald Test: } C(1) & =C(2)=C(3) \\
=C(4) & =0\end{aligned}$}} \\
\hline & & \multirow{2}{*}{ Coefficient } & \multicolumn{2}{|c|}{ 95\% Confidence Intervals } & \multicolumn{2}{|c|}{ 99\% Confidence Intervals } & & \\
\hline & & & Low & High & Low & High & F-Statistic & Chi-Square \\
\hline \multirow{4}{*}{ Overall } & LnIT & 1.0268 & 0.7500 & 1.3036 & 0.6610 & 1.3926 & \multirow{4}{*}{$40.3363^{* * *}$} & \multirow{4}{*}{$161.3451^{* * *}$} \\
\hline & LnTP & -0.5450 & -0.7419 & -0.3481 & -0.8052 & -0.2848 & & \\
\hline & LnSP & 0.1821 & 0.1420 & 0.2221 & 0.1291 & 0.2350 & & \\
\hline & X & -0.2055 & -0.3827 & -0.0284 & -0.4396 & 0.0286 & & \\
\hline \multirow{4}{*}{ Asia } & LnIT & 2.7718 & 2.4324 & 3.1111 & 2.3205 & 3.2230 & \multirow{4}{*}{$88.6741^{* * *}$} & \multirow{4}{*}{$354.6963 * * *$} \\
\hline & LnTP & -1.2429 & -1.5362 & -0.9497 & -1.6329 & -0.8530 & & \\
\hline & LnSP & 0.5497 & 0.4348 & 0.6646 & 0.3969 & 0.7025 & & \\
\hline & $x$ & 0.0603 & -0.1183 & 0.2389 & -0.1772 & 0.2977 & & \\
\hline \multirow{4}{*}{ Intercontinental } & LnIT & 0.8371 & 0.4910 & 1.1833 & 0.3769 & 1.2974 & \multirow{4}{*}{$48.4243^{* * *}$} & \multirow{4}{*}{$193.6973^{* * *}$} \\
\hline & LnTP & -0.3612 & -0.6746 & -0.0477 & -0.7780 & 0.0557 & & \\
\hline & LnSP & 0.1524 & 0.1147 & 0.1901 & 0.1023 & 0.2025 & & \\
\hline & $X$ & -0.0412 & -0.2197 & 0.1373 & -0.2786 & 0.1961 & & \\
\hline
\end{tabular}

Note: ${ }^{* * *}$ denotes significance at the 0.01 level.

By design, there are two popular estimation methods of cointegration regression for panel data, such as FMOLS and DOLS. The theory has shown that if the long-run coefficients of variance are consistent among panel units, then the DOLS estimator is appropriate and conversely, the FMOLS estimator is appropriate. Due to the significant difference in the long-run coefficient of variance between the source countries, from 0.4387 to 1.4375 (Table 2), the FMOLS method is chosen. Table 7 compares the estimation results by PMG/ARDL and FMOLS estimators for the three samples.

Table 7 shows that the FMOLS method only provides the four variables that are significant at the 0.05 or 0.01 level in the intercontinental sample. Meanwhile, in the overall sample, the $\operatorname{lnSP}$ variable is not significant. In addition, in the Asian sample, neither the $\operatorname{lnTP}$ variable nor the dummy variable $(X)$ is significant at the 0.05 level. In the significant variables, the estimated coefficient is different between the methods, but the sign is the same in all of the three samples. The bias between the two methods ranges from $2.73 \%$ to $56.23 \%$ for the $\operatorname{lnDT}$, from $4.26 \%$ to $31.58 \%$ for the $\operatorname{lnIT}$, and from $42.91 \%$ to $80.25 \%$ for the $\operatorname{lnSP}$. Despite certain differences, this study believes that the result from PMG/ARDL is more appropriate, as it gives more significant independent variables in most of the samples and its advantages are discussed in the aforementioned literature review.

Table 7. Differences in coefficients estimated by PMG/ARDL and FMOLS.

\begin{tabular}{|c|c|c|c|c|c|c|c|c|c|}
\hline \multirow{2}{*}{ Variable } & \multicolumn{3}{|c|}{ Overall Sample } & \multicolumn{3}{|c|}{ Asia Sample } & \multicolumn{3}{|c|}{ Intercontinental Sample } \\
\hline & ARDL & FMOLS & Bias & ARDL & FMOLS & Bias & ARDL & FMOLS & Bias \\
\hline LnIT & $1.0268^{* * *}$ & $0.9988^{* * *}$ & $\begin{array}{c}0.028 \\
(2.73 \%)\end{array}$ & $2.7718 * * *$ & $1.2133^{* * *}$ & $\begin{array}{c}1.5585 \\
(56.23 \%)\end{array}$ & $0.8371 * * *$ & $1.1326^{* * *}$ & $\begin{array}{c}0.2955 \\
(35.30 \%)\end{array}$ \\
\hline LnTP & $-0.5450 * * *$ & $-0.3729^{* * *}$ & $\begin{array}{c}0.1721 \\
(31.58 \%)\end{array}$ & $-1.2429 * * *$ & -0.0239 & & $-0.3612^{* * *}$ & $-0.3458^{* * *}$ & $\begin{array}{c}0.014 \\
(4.26 \%)\end{array}$ \\
\hline LnSP & $0.1821^{* * *}$ & 0.0179 & & $0.5497^{* * *}$ & $0.3138^{* * *}$ & $\begin{array}{c}0.2359 \\
(42.91 \%)\end{array}$ & $0.1524^{* * *}$ & $0.0301 * *$ & $\begin{array}{c}0.1223 \\
(80.25 \%)\end{array}$ \\
\hline$X$ & $-0.2055^{* *}$ & $-0.0608^{* * *}$ & $\begin{array}{c}0.1447 \\
(70.41 \%)\end{array}$ & 0.0603 & -0.0181 & & -0.0412 & $-0.0888^{* * *}$ & \\
\hline
\end{tabular}

Note: ${ }^{* * *}$ and ${ }^{* *}$ denote significance at the 0.01 and 0.05 levels, respectively.

\subsection{Discussion and Implications}

The results from this study show the tourism demand elasticities by income, own price, and substitute price among the major international tourism market regions to Vietnam. Accordingly, in the long-run, the income, own price, and substitute price have an impact on tourism demand as a general rule. First, the long-run elasticity of income shows that when the income of tourists increases by $1 \%$, international tourists to Vietnam increase by $1.03 \%$, of which tourists from Asia increase by $2.77 \%$ and tourists from the intercontinental 
market increase by $0.84 \%$. However, in the short-run, income elasticity only affects tourism demand in the source markets of China, Malaysia, Australia, Singapore, and Germany, but with different trends. The strong long-run income elasticities of tourism demand from Asian countries to Vietnam, such as China, Korea, Japan, Malaysia, and Singapore imply that demand is strongly influenced by income. This result supports many recent studies which show that most of the international tourism demand is income elastic (Lee 2011; Seetaram 2012; Cheng 2012; Untong et al. 2015; Álvarez-Diaz et al. 2015; Seetaram et al. 2016; Dogru et al. 2017). Tourism demand from intercontinental markets to Vietnam, such as the US, Australia, the UK, France, and Germany is relatively price inelastic, meaning that demand is less affected by income. Income-less elastic demand is also found in some markets, such as from the Philippines and Taiwan to Hong Kong (Song et al. 2010); from Japan and Malaysia to Thailand (Chaiboonsri et al. 2010); from the UK to Italy, Portugal, and Spain (Gatta and Falzon 2014); from China to Hong Kong, Macao, Germany, Italy, Canada, and the US (Lin et al. 2015); and from Singapore and Vietnam to Thailand (Ramos et al. 2017).

Next, the long-run own price elasticities show that when the own price increases by $1 \%$, international tourists to Vietnam decrease by $0.55 \%$, of which tourists from Asia decrease by $1.24 \%$ and tourists from intercontinental markets decrease by $0.36 \%$. Own prices also affect tourism demand in most of the source markets in the short term, except for Japan and Singapore, but with different signs of impact. These results imply that the pricing policy is only fully effective in the long-run. The own price elasticity shows that overall, international tourism demand to Vietnam is relatively less price elastic, but there are differences in market regions. It can be seen that demand from Asian countries is quite elastic, conversely, the demand from the intercontinental markets is less price elastic. The different price elastic tourism demand is demonstrated in many empirical studies. The price sensitive tourism demand is found in outbound tourism in the UK (Gatta and Falzon 2014); outbound tourism in Australia (Seetaram et al. 2016); most of the inbound tourism markets in Thailand (Ramos et al. 2017); from China to Macao, Australia, and New Zealand (Lin et al. 2015); and from China to Thailand (Untong et al. 2015). In contrast, less price-sensitive demand is also found from Germany and the UK to Spain (Álvarez-Diaz et al. 2015); from China to Hong Kong, Japan, Korea, Germany, Italy, and Canada (Lin et al. 2015); and from the Philippines to Thailand (Ramos et al. 2017).

Differences in income and own price elasticities between Asian and intercontinental source markets can be explained by the large difference in average income between the two regions. Specifically, the income per capita in the study period of the intercontinental sample was USD 39,124, 1.77 times higher than the Asian sample (USD 22,062). When the per capita income increases, traveling no longer becomes a luxury good since people can fully afford to travel without affecting essential living. In addition, the high income allows tourists in the intercontinental market to have higher affordability than tourists in the Asian market and price is not very important to them. This finding implies that in order to attract international tourists, in addition to an investment in tourism infrastructure development (as suggested by Nguyen 2021), Vietnam needs to focus on price policy to compete with regional destinations, especially attracting tourists from the Asian market. However, for tourists from transcontinental markets, price is not necessarily an important issue. Here, it is necessary to focus on the attraction and quality of the destination since many views believe that people in developed countries are accustomed to modern facilities and the high quality of service. On the other hand, different income elasticities from different regions and source markets are the basis for considering appropriate pricing policies.

The study results also show that the long-run substitute price elasticities of the overall, Asia, and the intercontinental market are $0.18,0.55$, and 0.15 , respectively. However, in the short-run, these elasticity coefficients have the opposite sign, as $-0.06,-0.12$, and -0.07 , respectively. Regarding each source market in the short-run, except for China, it is not significant, the substitute price elasticity coefficients have different directions of impact. Nevertheless, the substitute price elasticities are quite small, except for the Asian source 
market in the long-run. Therefore, it can be seen that most of the international market demand to Vietnam is inelastic to the substitute price. Tourism demand is less elastic by the substitute price. In addition, the substitute price elasticity has different signs in different markets as found in many studies (Li et al. 2006; Ouerfelli 2008; Song et al. 2010). The substitute price elasticities are quite small and have different signs in the long-run and the short-run, which is the basis for realizing that although in the long-run or the short-run, international tourists may consider destinations in countries in the lower Mekong as a substitute or complementary destination for Vietnam, but the magnitude of their impact is negligible. This implies that in addition to the competition, Vietnam and the lower Mekong countries need to cooperate in tourism development to both exploit each country's own advantages, as well as the advantages of the whole region, in order to be complementary destinations.

In this study, the autoregressive coefficients found in most of the source markets, except for Korea and Australia, are also significant to a certain extent. The autoregression coefficients in Asian markets all have a positive effect, but in the intercontinental market, they have a negative effect, except for the US. According to Dogru et al. (2017, p. 49), the lagged dependent variable "explains the intention of tourists to return to the destination or spread the destination's information, which may influence other people's choice behavior". Therefore, the autoregression coefficients are considered as a sign to search for different tourists' impressions from different source markets. To be more specific, tourists from China, Japan, Malaysia, Singapore, and the US showed signs of having a good impression, while tourists from major European markets namely the UK, France, and Germany showed signs of not having a good impression. This may be due to the fact that the destinations in Vietnam have not met the needs and desires of tourists from European countries. This issue needs to continue to be explored in order to find out the cause and to have appropriate policies for each source country.

Finally, the effects of uncertainties, intercepts, and trends are also significant to a certain extent. In the short term, international tourists to Vietnam in general and from market regions in particular are negatively affected by uncertainties. In particular, the Asian source market is more affected than the intercontinental source market. The international tourism demand to Vietnam from all of the source markets also tends to increase to varying degrees in the short-run.

\section{Conclusions}

Income and prices are the essential elements of economic theory in general and the theory of demand in particular. The primary role of income and prices in explaining the demand for international tourism has been thoroughly demonstrated by the large number of empirical studies that have been conducted over the past decades in different countries. However, there are differences in tourism demand depending on the determination of dependent and independent variables, the method of measuring them, as well as the estimation method and data of each country or region. This study uses the GDP per capita of source markets as a proxy for tourists' income. In addition, it is based on the CPI and exchange rate of source countries and Vietnam to establish a proxy for own and substitute prices. Different tourism demand elasticities by income and prices among market regions in the long-run, as well as major source markets in the short-run are found using Vietnam's data of the period 1995-2019 by a nonlinear panel ARDL approach.

The study results point out that income, own price, and substitute price have an influence on international tourism demand as a general rule in the overall, Asian, and intercontinental markets. In general, international tourism demand to Vietnam is income-sensitive, especially for the Asian market. However, this does not exist for the intercontinental market. The tourism demand from these markets to Vietnam is quite income inelastic. Except for own price in the Asian market, tourism demand from international tourism market regions to Vietnam is generally less elastic by the own and substitute prices, especially in the intercontinental market. However, differing views on the view of the Lower Mekong 
countries as substitute and complementary destinations for Vietnam are also found in the market regions in the long-run and short-run. Most of the source markets in Asia (China, Japan, Malaysia, Singapore) and the US have had a positive impact from the short-run autoregression coefficient. In contrast, the major international markets from Europe (the UK, France, and Germany) do not have this positive effect. In the period 1995-2019, uncertainties such as political instability, epidemics, economic recession, financial crisis, etc. have negatively affected the total demand for international tourism to Vietnam, as well as the Asia source market and intercontinental source market, but the most affected belongs to the Asian source market. These results are the basis for various implications, such as pricing policies for the tourism elastic market differing according to income, as well as sensitive and less sensitive markets to own prices; and for the competition and cooperation policy between Vietnam and countries in the lower Mekong region to jointly develop tourism.

The main contribution of this study is to supplement the empirical studies on tourism demand using a nonlinear panel ARDL approach with a diversified source market approach, including the overall, regions, and main source country. On the other hand, finding the specific tourism demand elasticities by income and prices from regions and source markets to Vietnam is the basis for suggesting tourism policies in general and for Vietnam in particular for different market segments. However, due to data source limitations, differences between tourist groups have not been considered and it may represent opportunities for further research.

Funding: This research was funded by University of Economics and Law, Vietnam National University, Ho Chi Minh, Vietnam, under grant number 4-2021.

Institutional Review Board Statement: Not applicable.

Informed Consent Statement: Not applicable.

Data Availability Statement: Data on international tourists to Vietnam is collected from various sources, they are retrieved from: https:/ / www.gso.gov.vn/px-web-2/?pxid=V0825\&theme=Th\%C6 $\%$ B0 $\%$ C6 $\%$ A1ng $\% 20$ m $\% 1 \% B A \% A 1 i \% 2 C \% 20$ gi $\%$ C3\%A1\%20c\%E1\%BA\%A3 (accessed on 28 October 2021); and https:/ / vietnamtourism.gov.vn/index.php/statistic/international (accessed on 28 October 2021); GDP per capita, CPI and exchange rates of countries to the dollar are retrieved from: https: / / data.worldbank.org/ (accessed on 28 October 2021).

Acknowledgments: The author is grateful to the three anonymous reviewers and academic editor whose comments have contributed to improving the quality of this paper.

Conflicts of Interest: The authors declare no conflict of interest.

\section{Appendix A}

\section{Appendix A.1. Panel Cointegration Analysis}

To analyze the cointegration relationship among the variables in the panel data model, this study uses seven test statistics of Pedroni (1999) with the assumption of "Individual Intercept" and "Individual Intercept and Invidual trend". In addition, the Kao test, developed by Kao (1999) with the null hypothesis of no cointegration is also applied. Table A1 below summarizes the cointegration test results and shows that most of the tests (5/7 tests) are significant at the 0.01 level in the case of "Individual Intercept and Individual trend" for all three samples as the overall sample, Asia sample, and intercontinental sample. By contrast, in the case of "Individual Intercept", the tests are almost not significant at the 0.05 level, except for the case of the overall sample with $1 / 7$ tests, which is significant at the 0.05 level. Therefore, the Pedroni test does not give clear results. However, the results of the Kao test give significance at the 0.05 level of all three samples. Therefore, the null hypothesis is rejected and the alternative hypothesis is accepted, indicating that a cointegration relationship exists between the variables of all three samples. In other words, the variables in all three samples have a long-run association. 
Table A1. Results of panel cointegration analysis.

\begin{tabular}{|c|c|c|c|c|c|c|c|}
\hline \multirow[b]{2}{*}{ Method } & \multirow[b]{2}{*}{ Statistic } & \multicolumn{2}{|c|}{ Overall Sample } & \multicolumn{2}{|c|}{ Asia Sample } & \multicolumn{2}{|c|}{ Intercontinental Sample } \\
\hline & & $\begin{array}{l}\text { Individual } \\
\text { Intercept }\end{array}$ & $\begin{array}{l}\text { Trend and } \\
\text { Intercept }\end{array}$ & $\begin{array}{c}\text { Individual } \\
\text { Intercept }\end{array}$ & $\begin{array}{l}\text { Trend and } \\
\text { Intercept }\end{array}$ & $\begin{array}{c}\text { Individual } \\
\text { Intercept }\end{array}$ & $\begin{array}{l}\text { Trend and } \\
\text { Intercept }\end{array}$ \\
\hline \multirow{7}{*}{ Pedroni test } & $\begin{array}{c}\text { Panel } \\
\text { v-Statistic }\end{array}$ & $1.8675^{* *}$ & $6.6942^{* * *}$ & $1.4166^{*}$ & $3.8283^{* * *}$ & 1.1384 & $3.9529 * * *$ \\
\hline & $\begin{array}{c}\text { Panel } \\
\text { rho-Statistic }\end{array}$ & -0.2130 & -1.6997 & 0.1954 & 0.2600 & -0.2277 & -0.7345 \\
\hline & $\begin{array}{c}\text { Panel } \\
\text { PP-statistic }\end{array}$ & -1.3908 * & $-10.068^{* * *}$ & -0.7757 & $-4.4510^{* * *}$ & -1.0207 & $-4.7290 * * *$ \\
\hline & $\begin{array}{c}\text { Panel } \\
\text { ADF-Statistic }\end{array}$ & 0.6889 & $-12.056^{* * *}$ & -0.7911 & $-4.4454^{* * *}$ & $-1.3405 *$ & $-4.7699 * * *$ \\
\hline & $\begin{array}{c}\text { Group } \\
\text { rho-Statistic }\end{array}$ & 1.1931 & 1.1429 & 1.2366 & 1.2418 & 0.4545 & 0.3585 \\
\hline & $\begin{array}{c}\text { Group } \\
\text { PP-Statistic }\end{array}$ & $-1.6327^{*}$ & $-6.1120^{* * *}$ & -1.0454 & $-4.4685^{* * *}$ & -1.2560 & $-4.2059 * *$ \\
\hline & $\begin{array}{c}\text { Group } \\
\text { ADF-Statistic }\end{array}$ & -0.6521 & $-7.9811^{* * *}$ & -0.1151 & $-4.3079 * * *$ & $-1.3730 *$ & $-5.3533^{* *}$ \\
\hline Kao test & $\mathrm{t}$-Statistic & $-2.2516^{* *}$ & & $-1.9520 * *$ & & $-2.4680^{* * *}$ & \\
\hline
\end{tabular}

Note: Trend and intercept are the individual trend and individual intercept; ${ }^{* *},{ }^{* *}$ and ${ }^{*}$ denote significance at the $0.01,0.05$, and 0.10 levels, respectively.

\section{Appendix A.2. FMOLS Estimation}

The results of the estimation of coefficients by the FMOLS method in Table A2 show that only the intercontinental sample for all of the four variables is significant at the 0.01 or 0.05 level. The variable lnSP is not significant in the overall sample, while the other three variables are all significant at the 0.01 level. The Asia sample has the least significant number of variables with two variables, $\operatorname{lnIT}$ and $\operatorname{lnSP}$, at the 0.01 level.

Table A2. Estimated coefficients by the FMOLS method.

\begin{tabular}{ccccccc}
\hline \multirow{2}{*}{ Variable } & \multicolumn{2}{c}{ Overall Sample } & \multicolumn{2}{c}{ Asia Sample } & \multicolumn{2}{c}{ Intercontinental Sample } \\
\cline { 2 - 6 } & Coefficient & t-Statistic & Coefficient & t-Statistic & Coefficient & t-Statistic \\
\hline LnIT & 0.9988 & $8.09^{* * *}$ & 1.2133 & $4.57^{* * *}$ & 1.132575 & $6.06^{* * *}$ \\
LnTP & -0.3729 & $-5.03^{* * *}$ & -0.0239 & -0.11 & -0.345838 & $-4.97^{* * *}$ \\
LnSP & 0.0179 & 1.05 & 0.3138 & $6.02^{* * *}$ & 0.030072 & $2.47^{* *}$ \\
X & -0.0608 & $-2.76^{* * *}$ & -0.0181 & -0.23 & -0.088757 & $-3.90^{* * *}$ \\
\hline
\end{tabular}

Note: Panel method is grouped estimation; cointegrating equation deterministic is $\mathrm{C} @$ trend; long-run covariance estimates are Bartlett kernel and Newey-West fixed bandwidth; ${ }^{* *}$ and ${ }^{* *}$ denote significance at the 0.01 and 0.05 levels, respectively.

\section{References}

Álvarez-Diaz, Marcos, Manuel González-Gómez, and Maria Soledad Otero-Giráldez. 2015. Research note: Estimating price and income demand elasticities for Spain separately by the major source markets. Tourism Economics 21: 1103-10. [CrossRef]

Araña, Jorge E., and Carmelo J. León. 2008. The impact of terrorism on tourism demand. Annals of Tourism Research 35: 299-315. [CrossRef]

Banerjee, Anindya, Juan J. Dolado, John W. Galbraith, and David Hendry. 1994. Co-Integration, Error Correction, and the Econometric Analysis of Non-Stationary Data. New York: Oxford University Press.

Blackburne, Edward F., III, and Mark W. Frank. 2007. Estimation of Nonstationary Heterogeneous Panels. The Stata Journal: Promoting Communications on Statistics and Stata 7: 197-208. [CrossRef]

Chaiboonsri, Chukiat, Jittaporn Sriboonjit, Thanes Sriwichailamphan, Prasert Chaitip, and Songsak Sriboonchitta. 2010. A panel cointegration analysis: An application to international tourism demand of Thailand. Annals of the University of Petrosani Economics 10: 69-86.

Cheng, Ka Ming. 2012. Tourism demand in Hong Kong: Income, prices, and visa restrictions. Current Issues in Tourism 15: 167-81. [CrossRef]

Croes, Robertico R., and Manuel Vanegas Sr. 2005. An econometric study of tourist arrivals in Aruba and its implications. Tourism Management 26: 879-90. [CrossRef] 
Crouch, Geoffrey I. 1992. Effect of income and price on International tourism. Annals of Tourism Research 19: 643-64. [CrossRef]

Crouch, Geoffrey I. 1996. Demand elasticities in international marketing: A metaanalytical application to tourism. Journal of Business Research 36: 117-36. [CrossRef]

Dogru, Tarik, and Ercan Sirakaya-Turk. 2018. Modeling Turkish outbound tourism demand using a dynamic panel data approach. Tourism and Hospitality Research 18: 411-14. [CrossRef]

Dogru, Tarik, Ercan Sirakaya-Turk, and Geoffrey I. Crouch. 2017. Remodeling international tourism demand: Old theory and new evidence. Tourism Management 60: 47-55. [CrossRef]

Dritsakis, Nikolaos. 2004. Cointegration analysis of German and British tourism demand for Greece. Tourism Management 25: 111-19. [CrossRef]

Enders, Walter. 2004. Applied Econometric Time Series, 2nd ed. New York: John \& Wiley.

Gatta, William, and Joseph Falzon. 2014. British tourism demand elasticities in Mediterranean countries. Applied Economics 46: 3548-61. [CrossRef]

General Statistics Office of Vietnam. 2021. Business Results of the Tourism Industry. Available online: https://www.gso.gov.vn/pxweb-2/?pxid=V0825\&theme=Th\%C6\%B0\%C6\%A1ng\%20m\%E1\%BA\%A1i\%2C\%20gi\%C3\%A1\%20c\%E1\%BA\%A3 (accessed on 28 October 2021).

Granger, Clive W. J., and Paul Newbold. 1974. Spurious regressions in econometrics. Journal of Econometrics 2: 111-20. [CrossRef]

Greene, William H. 2008. Econometric Analysis. Harlow: Pearson Prentice Hall.

Kao, Chihwa. 1999. Spurious regression and residual-based tests for cointegration in panel data. Journal Econometrics 90: 1-44. [CrossRef]

Kulendran, Nada, and Stephen F. Witt. 2001. Cointegration versus least squares regression. Annals of Tourism Research 28: 291-311. [CrossRef]

Kumar, Nikeel, Kuma Ronald Ravinesh, Patel Arvind, Hussain Shahzad, Syed Jawad, and Stauvermann Peter Josef. 2020. Modelling inbound international tourism demand in small Pacific Island countries. Applied Economics 52: 1031-47. [CrossRef]

Kraipornsak, Paitoon. 2011. The world economy, competition, external shocks and demand for international tourist arrivals in Thailand. International Journal Trade and Global Markets 4: 93-118. [CrossRef]

Lee, Koon Nam Henry. 2011. Estimating demand elasticities for intra-regional tourist arrivals to Hong Kong-The "bounds" testing approach. Applied Economics Letters 18: 1645-54. [CrossRef]

Li, Gang, Kevin K. F. Wong, Haiyan Song, and Stephen F. Witt. 2006. Tourism demand forecasting: A time varying parameter error correction model. Journal of Travel Research 45: 175-85. [CrossRef]

Lim, Christine. 1997. Review of international tourism demand models. Annals of Tourism Research 24: 835-49. [CrossRef]

Lim, Christine. 2004. The major determinants of Korean outbound travel to Australia. Mathematics and Computers in Simulation 64: 477-85. [CrossRef]

Lin, Vera Shanshan, Anyu Liu, and Haiyan Song. 2015. Modeling and Forecasting Chinese Outbound Tourism: An Econometric Approach. Journal of Travel and Tourism Marketing 32: 34-49. [CrossRef]

Mangion, Marie-Louise, Ramesh Durbarry, and M. Thea Sinclair. 2005. Tourism competitiveness: Price and quality. Tourism Economics 11: 45-68. [CrossRef]

Martin, Christine A., and Stephen F. Witt. 1989. Forecasting tourism demand: A comparison of the accuracy of several quantitative methods. International Journal of Forecasting 5: 7-10. [CrossRef]

Munoz, Teresa Gari. 2007. German demand for tourism in Spain. Tourism Management 28: 12-22. [CrossRef]

Narayan, Paresh Kumar, and Seema Narayan. 2005. Estimating income and price elasticities of imports for Fiji in a cointegration framework. Economic Modelling 22: 423-38. [CrossRef]

Nguyen, Quang Hai. 2021. Impact of Investment in Tourism Infrastructure Development on Attracting International Visitors: A Nonlinear Panel ARDL Approach Using Vietnam's Data. Economies 9: 131. [CrossRef]

Nkoro, Emeka, and Aham Kelvin Uko. 2016. Autoregressive Distributed Lag (ARDL) cointegration technique: Application and interpretation. Journal of Statistical and Econometric Methods 5: 63-91.

Ouerfelli, Chokri. 2008. Co-integration analysis of quarterly European tourism demand in Tunisia. Tourism Management 29: 127-137. [CrossRef]

Pedroni, Peter. 1999. Critical values for cointegration tests in heterogeneous panels with multiple regressors. Oxford Bulletin of Economics and Statistics 61: 653-670. [CrossRef]

Peng, Bo, Haiyan Song, and Geoffrey I. Crouch. 2014. A meta-analysis of international tourism demand forecasting and implications for practice. Tourism Management 45: 181-93. [CrossRef]

Pesaran, M. Hashem, Yongcheol Shin, and Richard J. Smith. 2001. Bounds testing approaches to the analysis of level relationships. Journal of Applied Econometrics 16: 289-326. [CrossRef]

Ramos, Vicente, Akarapong Untong, and Mingsarn Kaosaard. 2017. ASEAN's intra-regional tourism demand to Thailand. Asia Pacific Journal of Tourism Research 22: 909-21. [CrossRef]

Ritchie, Brent W. 2004. Chaos, crises and disasters: A strategic approach to crisis management in the tourism industry. Tourism Management 25: 669-83. [CrossRef]

Salisu, Afees A., and Kazeem O. Isah. 2017. Revisiting the oil price and stock market nexus: A nonlinear Panel ARDL approach. Economic Modelling 66: 258-71. [CrossRef] 
Samirkaş, Meryem, and Mustafa Can Samirkaş. 2015. The Impact of Exchange Rate on Tourism Industry: The Case of Turkey. In Handbook of Research on Global Hospitality and Tourism Management. Hershey: IGI Global, Chapter 54. pp. 1177-90. [CrossRef]

Seetaram, Neelu, Peter Forsyth, and Larry Dwyer. 2016. Measuring price elasticities of demand for outbound tourism using competitiveness indices. Annals of Tourism Research 56: 65-79. [CrossRef]

Seetaram, Neelu. 2012. Immigration and international inbound tourism: Empirical evidence from Australia. Tourism Management 33: 1535-43. [CrossRef]

Shafiullah, Muhammad, Luke Emeka Okafor, and Usman Khalid. 2018. Determinants of International Tourism Demand: Evidence from Australian States and Territories. Tourism Economics 25: 274-96. [CrossRef]

Song, Haiyan, and Gang Li. 2008. Tourism demand modelling and forecasting-A review of recent research. Tourism Management 29: 203-220. [CrossRef]

Song, Haiyan, and Kevin KF Wong. 2003. Tourism demand modelling: A time-varying parameter approach. Journal of Travel Research 42: 57-64. [CrossRef]

Song, Haiyan, and Stephen F. Witt. 2003. Tourism forecasting: The general-to-specific approach. Journal of Travel Research 42: 65-74. [CrossRef]

Song, Haiyan, Jae H. Kim, and Shu Yang. 2010. Confidence intervals for tourism demand elasticity. Annals of Tourism Research 37: 377-96. [CrossRef]

Song, Haiyan, Stephen F. Witt, and Gang Li. 2003. Modelling and forecasting the demand for Thai tourism. Tourism Economics 9: 363-87. [CrossRef]

Song, Haiyan, Stephen F. Witt, and Gang Li. 2009. The Advanced Econometrics of Tourism Demand. New York: Routledge.

Studenmund, Arnold H. 2006. Using Econometrics: A Practical Guide, 5th ed. Boston: Pearson Education.

The World Bank. 2021. World Bank Open Data. Available online: https:/ /data.worldbank.org/ (accessed on 28 October 2021).

Untong, Akarapong, Vicente Ramos, Mingsam Kaosa-Ard, and Javier Rey-Maquieira. 2015. Tourism Demand Analysis of Chinese Arrivals in Thailand. Tourism Economics 21: 1221-34. [CrossRef]

Uysal, Muzaffer, and Joln L. Crompton. 1984. Determinants of demand for international tourist flows to Turkey. Tourism Management 5: 288-97. [CrossRef]

Vanegas, Manuel, Sr., and Robertico R. Croes. 2000. Evaluation of demand: US tourist to Aruba. Annals of Tourism Research 27: 946-63. [CrossRef]

Vietnam National Administration of Tourism. 2020. Vietnam Tourism Annual Report 2019; Hanoi: Labor Publishing House, ISBN 978-604-301-333-7.

Vietnam National Administration of Tourism. 2021. International Visitors. Available online: https://vietnamtourism.gov.vn/index. $\mathrm{php} /$ statistic/international (accessed on 28 October 2021).

Wooldridge, Jeffrey M. 2015. Introductory Econometrics: A Modern Approach. Boston: Cengage Learning, ISBN-13 978-1-111-53104-1.

Xu, Lizhi, Shouyang Wang, Jingjing Li, Ling Tang, and Yanmin Shao. 2018. Modelling International Tourism Flows to China: A panel data analysis with the gravity model. Tourism Economics 25: 1047-69. [CrossRef] 